\title{
$9 \quad$ Novel Religious Practices as Imaginative Works
}

After the inauguration of the new temple on New Year's Day of 2008, Ox Horn organized a five-day pilgrimage to China, from July 5-9. Because the completion of the new temple had realized a long-awaited dream of many Ox Horn villagers, this pilgrimage won strong support from local residents and village emigrants living in Taiwan. Including pilgrims from other islands, more than 300 people took part. In the procession, one could see the temple committee members holding statues of Wuling Gong and the Lady of Linshui, young people carrying sedan chairs and puppets, women playing drums and gongs, and pilgrims following behind.

That this pilgrimage was aimed at more than religious renewal is evident in its name: "Matsu-Ningde First Sail: Changle Pilgrimage." That is, they did not directly head for their ancestral temple in Changle, but instead undertook an elaborately planned journey across the Taiwan Strait, starting from Taiwan and arriving in northeast Fujian Province (Map 1). The five-day itinerary was as follows:

$$
\begin{aligned}
& 5 \text { July-Keelung, Taiwan } \rightarrow \text { Matsu } \rightarrow \text { Ningde, China } \\
& 6 \text { July-Ningde } \rightarrow \text { Pingnan (Baishuiyang Scenic Spot) } \\
& 7 \text { July_-Pingnan } \rightarrow \text { Gutian (Linshui Temple) } \rightarrow \text { Fuzhou } \\
& 8 \text { July_Fuzhou } \rightarrow \text { Changle (Longshan Temple) } \rightarrow \text { Fuzhou } \\
& 9 \text { July_Fuzhou } \rightarrow \text { Mawei } \rightarrow \text { Matsu }
\end{aligned}
$$

The organizers rented the Hofu Ferry and departed from Keelung Port in Taiwan, where they invited officials from the Ministry of Transportation and the mayor of Keelung to a press conference. After stopping in Matsu to pick up local residents, the ferry proceeded northwest into Sandu'ao Port and reached Ningde City in Fujian, China, 
where the city government welcomed the pilgrims in celebratory style. The next day, the pilgrims boarded a bus and headed northwest to the Baishuiyang Scenic Spot, before traveling south to the Linshui Temple in Gutian County, the root temple of the Lady of Linshui. They then continued further southward to Fuzhou, where they finally arrived at the ancestral Wuling Temple in Changle.

We may wonder why a pilgrimage held by people from Matsu would choose Keelung as its starting point? Why was Ningde, a city not well known in Taiwan, chosen as the point of entry into China? Why did a pilgrimage to the ancestral temple have to take a detour towards the northeast and arrive at Changle only after visiting the Linshui Temple in Gutian?

This chapter begins with this pilgrimage and moves on to discuss the successive, newly invented religious practices initiated by the islanders in the first decade of the twenty-first century, including Matsu-China "direct-sail" pilgrimages, the myth that "Goddess Mazu was buried in the Matsu Islands," ascension rituals for the goddess, and the construction of her tomb and a giant statue. The "Goddess Unbound" (Weller 2019), material practices, and invented rituals will also be discussed. I will first explicate how these inventions were responses to the drastic changes in Taiwan and China during the period 2000-10 when, in particular, a series of "direct links" were promulgated to connect Taiwan and China. These transformations seriously challenged the status of the Matsu Islands, and left islanders with a great sense of confusion and uncertainty about their future. The Matsu people thus devised various rituals, myths, and material practices to break through the cross-strait political impasses. Second, I will show that these innovative religious practices are not only responses to the changing cross-strait political and economic situations, but also the processes of the islanders' subjectivity and subjectification. It is through these mechanisms that they attempt to recentralize themselves, create new social relations, and imagine novel possibilities for the islands.

\section{Imagining the "Cross-Strait Economic Zone" in the Neoliberal Era}

After the Warzone Administration was disbanded in 1992, the progressive retreat of the army had severe effects on the local economy. When 


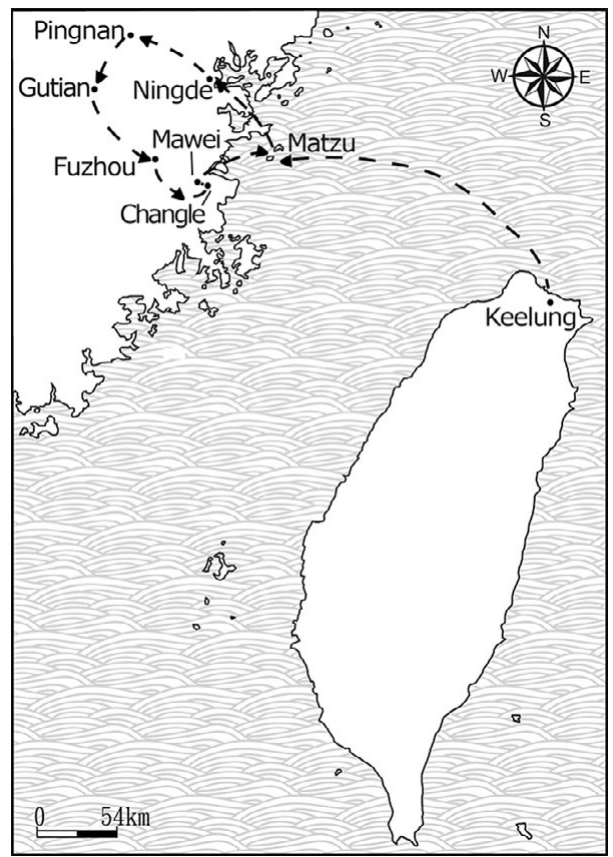

Map 9.1 The route of the Ox Horn pilgrimage

the "three great links" across the Taiwan Strait, by which flights, sea voyages, and the post could bypass Matsu and move directly between China and Taiwan, were mooted early in the twenty-first century and finally implemented in 2008, the islanders experienced a strong sense of doubt about their future and even felt abandoned by the Taiwan government. These worries were revealed in the Matsu people's own accounts: they used to consider themselves "the Fortress of the Taiwan Strait" (taihai baolei) and "a springboard for anticommunism" (fangong tiaoban). Nowadays, in sharp contrast, terms like "orphans" (gu'er) or "secondrate citizens" (erdeng gongmin) frequently appear in Matsu Online, expressing people's disaffection owing to what they see as neglect by the Taiwan government.

With this in mind, we can better understand why the Matsu-initiated pilgrimage to China was designed to start in Taiwan and pass through Matsu before reaching China: it is an expression of hope that Matsu can become a mediator between Taiwan and China. Looking again at 
Map 9.1, we can see that the pilgrimage route's clear message is that Matsu is no longer an insignificant archipelago between Taiwan and China, but rather a "central point" connecting them. In other words, Matsu's people imagine the pilgrimage as transforming their marginal position and bringing them back as the focus of cross-strait relations.

It was the then head of the County Tourism Bureau and secretary of the temple committee, Cao Eryuan, who offered up this vision. Cao studied agriculture at Tunghai University in Taichung, Taiwan through the guaranteed admission program. Not long after arriving in Taichung, he appealed to other schoolmates from Matsu to follow him there to study, establishing the Taichung Matsu Association and inviting Matsu students from other nearby schools to participate. This was an early indication of Cao's gregarious nature and his desire for collaboration, as well as his ability to make connections far and wide. He has spoken about how he absorbed democratic ideas while studying in Taiwan, and how he participated in opposition activities to fight for independence upon returning to Matsu (E. Cao 1988). What had the deepest impact on him, however, was his experience working with military officials in an agricultural improvement station after returning home.

At that time, the station was still controlled by the military, and was in the midst of carrying out a "war against isolation and hardship" (fan gukun zuozhan jihua). This program was intended to improve Matsu's agricultural production, as well as to encourage young people to engage in "pioneering work" and "collaborate [with the army] to build factories" (hezuo zaochang). Most of the funding for the project was provided by the army. The remainder came in the form of loans from the military to young people. In order not to lose money, however, the military officials demanded interest rates even higher than those charged by banks. When Cao Eryuan told the officials that young people would only be able to participate in the program when interest rates were lowered, the military's response was to fret about potential financial losses. In a fiery argument, one officer even accused him of being a "turncoat." Cao said:

I was really disappointed. These military officials weren't actually interested in developing Matsu, and they didn't really want young people to participate. The whole thing went on for a year without a resolution. ... [That is why] when I became the head of the Tourism Bureau, I launched direct flights between Matsu and Meizhou [in Fujian], and later one to Ningde to bring in more 
people and to make more connections for Matsu. Only with more people will Matsu be able to prosper.

Bring in more people, make more connections to Matsu: after his experience with the army, Cao became increasingly fixated on this idea, which was consistent with his natural inclination to bring people together. Like many people of his generation, he returned to Matsu to serve in government after studying in Taiwan. He began at the agricultural improvement station, moved on to the County Government, and gradually climbed his way up. When he eventually became the head of the Tourism Bureau, he had a chance to put his convictions into action. At the time, there were radical changes in the relationship between the two sides of the Taiwan Strait; with the implementation of the "three great links," Matsu's marginalization came to a head. As Matsu was seeking a new position for itself, his goal developed into creating new links for the islands. In an interview in 2008, he proudly said:

When I was invited to give a talk at the Ningde Tourism Exhibition last year, I told the audience, "Matsu is not just an archipelago along the coast of Fujian; neither should it be considered as Taiwan's outlying islands. Matsu belongs to the world! If I draw a circle around Matsu, it will encompass all of you. In the future Matsu will be able to connect you with Taiwan. ...Matsu is a connecting point in the Taiwan Strait, but it is also the central point.... We will soon launch a direct-sailing route to Ningde." "After the demise of the War Zone Administration," he went on to say, "Matsu should play the role of fulcrum in the balance of cross-strait relations."

In other words, the direct-sailing pilgrimage is an important medium, through which he hoped to be able to bring to fruition his long-term thoughts about how the islands could prosper in the period after military rule. More importantly, pilgrimage was also a means of connecting his own life experiences with the collective desire of recentralization, since the direct-sailing pilgrimage was seen as a way to draw out the hope and imagination that could reverse Matsu's marginalization and restore it as a focal point between China and Taiwan.

From this perspective, we can understand why the pilgrimage started from Keelung in Taiwan, and also why a pre-trip, formal press conference was held, to which government officials were invited. But why was the relatively obscure city of Ningde chosen as the point of entry into 
northeast Fujian? Cao Eryuan explained this as a way to explore a new route in addition to the existing "three small links" between JinmenXiamen and Matsu-Fuzhou. Moreover, he pointed out that Ningde could connect to north Fujian, further north to Zhejiang Province, and even to Shanghai after the 2009 opening of the Wen-Fu (WenzhouFuzhou) high speed railway. Convinced that Ningde had the potential to become an economic relay point between Taiwan and Shanghai, they thought that such a route could make Keelung-Matsu-Ningde-Shanghai into a new path for economic development, as well as a unique cultural route combining tourism (to east and north Fujian) and religion (through the Lady of Linshui) (see also Keelung-Matsu-Ningde 2008).

This idea encapsulates the Matsu people's imagination of the "Western Taiwan Strait Economic Zone" (haixia xi'an jingjiqu, hereafter "CrossStrait Economic Zone"), a policy the Fujian government proposed at the beginning of this century. The Cross-Strait Economic Zone was first proposed in 2004 as both a political strategy and a regional economic development plan (Haixi: cong 2009). Its ambit stretches beyond the province itself, most importantly east to Taiwan, and its main goal is to increase development in Fujian, which, due to the longstanding tensions in cross-strait relations, had been neglected relative to the Yangtse and Pearl River deltas. This is to be accomplished by augmenting cross-strait exchanges, developing modern transportation and networks, and advancing manufacturing and tourism along the strait (Haixi tengfei 2009).

For example, one of its projects was the construction of the Wen-Fu Railroad, launched in 2005 and completed in 2009. This route reduced the travel time between Fuzhou and Shanghai from fourteen hours to a mere five, and Ningde is the first northbound stop from Fuzhou. In the past, the development of Ningde had been rather limited and relatively slow compared to other southern cities in Fujian owing to its proximity to Sandu'ao, an important military port. With its high-speed rail connection, the Matsu people now see Ningde as a place with high potential for development. Envisioning the future, Cao Eryuan said:

Very soon, this place [Ningde] can attract people from the Yangtse river delta, Hangzhou, Wenzhou. [If the sea route is implemented] they can come to Matsu first before continuing on to Taiwan. That way, Matsu will become a center and a kind of hub. ... We will have our own niche. 
This statement shows that this pilgrimage was rooted in an important imaginary and hope for the future: in short, Cao longed for Matsu to join in the development of the Cross-Strait Economic Zone, and by making the islands a link between the mainland and Taiwan, Matsu would become a key pivot in the region.

From a wider perspective, the Cross-Strait Economic Zone is an example of neoliberal design "with Chinese characteristics" (Harvey 2005; Ong 2006: 98-9). Since the 1980s, many such economic zones have appeared along China's southeastern coast, and the Chinese government is in the process of constructing highways and high-speed railways to link these zones with interior cities. However, one consequence of this policy is that the cities in these zones are perpetually in ferocious competition, each scrambling to outdo its neighbors in business and cultural affairs. An important question for their ruling elites has become how to produce cities or regions with distinctive qualities and attractions (Harvey 1990: 295; 2005: 132).

It is from this neoliberal perspective that we can better comprehend the enthusiasm of the people in Ningde to make this pilgrimage a successfor them, connecting to Taiwan through Matsu was a major breakthrough. The Ningde government's website trumpeted how the pilgrimage could accelerate development of tourism and religious culture in northern Fujian (Mou 2008). The city's top administrator came to the welcoming ceremony held in Ningde's city hall on July 5 and declared,

The Hofu Ferry brought a full boat of Taiwanese fellow countrymen to Ningde, realizing the first direct-sailing between Ningde and Taiwan, and marking a historic breakthrough in the exchange and cooperation of Ningde and Taiwan" (Ningde xiying 2008).

Afterward, he talked about developing Ningde into an important city in the Cross-Strait Economic Zone:

Ningde is a large port bursting with business opportunities ... the entire city ... [will in the future] put forward its best efforts to push [Ningde into becoming] a central city in the northeast wing of the Cross-Strait Economic Zone (ibid.).

Thus, this pilgrimage was significant for Ningde in many important ways: not only did it allow the city to transcend its previous status as a military port with little contact with the outside world, it also 
immediately gave it a higher profile and greater prominence in the CrossStrait Economic Zone. By carrying off the pilgrimage successfully, Ningde recreated itself as a place with economic and cultural potential. Thus, the pilgrimage is without a doubt the result of a joint vision of a new politico-economic zone in the neoliberal age.

\section{Virtual Recentralization through the Welcoming Ceremony}

We can go one step further by exploring exactly how this pilgrimage brought about the imaginary recentralization of Matsu. To facilitate the arrival of the pilgrims, Ningde city officials were extraordinarily cooperative with regard to customs and transportation. The city government cleared the port to welcome the ferry, and in order to process the Matsu pilgrims quickly they erected a temporary customs office in a former cement factory next to the port. The pilgrims were treated with the utmost courtesy during the pilgrimage events over the following five days. For instance, the group was escorted everywhere by important officials, such as Ningde's deputy mayor and the deputy chairman of the city's People's Congress, and police were stationed at every intersection along the route to assist with traffic control. The nine tour buses carrying the pilgrims seldom encountered a red light and roamed the streets with ease.

A carefully designed welcoming ceremony further reinforced the image of Matsu linking China and Taiwan across the Strait. Just after disembarking, the pilgrims were escorted to an auditorium where a long red carpet had been laid at the entrance to welcome them. On either side, arrays of people danced, played gongs and drums, and set off firecrackers in cordial welcome. Walking into the auditorium, they were confronted by a gigantic picture depicting a boat sailing westward toward the Lady of Linshui (Fig. 9.1). On either side hung a large golden medallion decorated with shining lights, with Taiwan, Matsu, and Ningde prominently marked, making explicit the significance of the direct pilgrimage in binding together the three places. The design and decorations of the event palpably conveyed the Matsu people's role as intermediary, for it was they who had managed to connect Ningde and Taiwan for the first time. 


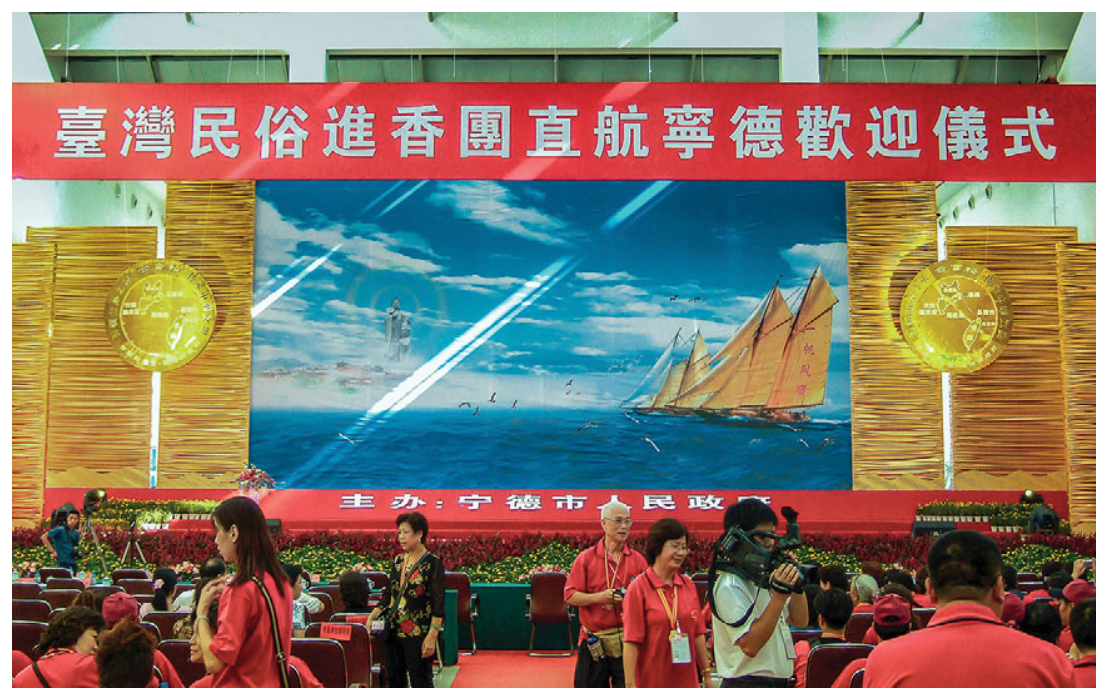

Fig. 9.1 The auditorium for the welcoming ceremony in Ningde (Photo by the author)

Apart from the pilgrims, the auditorium was full of officials from all levels, and media from the Ningde area and even Fuzhou. Leaders from both sides - the top administrator of Ningde and the county commissioner of Matsu-delivered long speeches brimming with visions of future political and economic interaction. They formalized their alliance by exchanging gifts, including votive tablets (bian'er) and local products (techan). In fact, such political alliances were stressed throughout the pilgrimage; wherever the pilgrims went, local government officials held banquets in their honor, and accounts and photographs of the numerous ceremonies during the trip were published in newspapers and on websites in Matsu, Taiwan, and China. The imaginations here differed from those expressed in traditional pilgrimages through religious symbols, legends of saints, or sacred topography (Turner 1967; 1968; Turner and Turner 1978); here, what made possible Matsu's imaginary of a mediatory role, or more specifically, its virtual recentralization, was the careful organization of rituals, the administrative and transportation privileges extended to the pilgrims, and the accounts of the journey rapidly disseminated by the media. 


\section{Extending Sociocultural Space}

We may wonder why this political and economic project should have been realized by means of a religious activity such as a pilgrimage. Sangren (2000: 100) has shown that the relationship between a branch temple and its ancestral temple is a special, cultural-spatial one. It operates by a mechanism that is not readily reducible to political orders, as has been further shown by Yang's research (2004: 228) on the ritual space of the Goddess Mazu stretching across China and Taiwan. In this pilgrimage, we see that the cultural-spatial relation between Ox Horn and its homeland, Changle, was expanded to connect Taiwan and northern Fujian. It imaginatively articulated the Matsu residents' changing political and economic circumstances (see Kapferer, Eriksen, and Telle 2009: 3) and helped them to envision new prospects for their future.

To understand this contemporary pilgrimage, we must further examine the different types of Taiwanese pilgrimage from which the Matsu people have borrowed. The first, pilgrimages to ancestral temples, occur regularly and the entire community usually participates in them. Most famous of these is the annual pilgrimage organized by the Zhenlan Temple in Daiia (Chang 2003; Sangren 1987). In a second type of pilgrimage, which scholars have studied less, owing to their irregularity, people or interest groups organize visits to popular temples that are combined with tourism. These are usually more impromptu and have no fixed route or destination.

The pilgrimage held by Ox Horn combined these two types. It had the first type's community-based and root-searching quality - the destination was their homeland, Changle, and the more than 300 participants were mainly Ox Horn residents and their relatives in Taiwan. They included couples, parents, and children, and sometimes relatives from three generations. One family seized on the pilgrimage as a chance for a "reunion" (jiaju) of twenty-six of its members. Many older people went along to seek the well-being of their families; having experienced warfare and poverty, many of them led austere lives and consented to travel far from home only for this reason. Younger participants saw the pilgrimage as a chance to 
show filial piety to their elders. I also observed many emigrants bring their families back from Taiwan to meet their relatives in Matsu.

And yet the pilgrimage also had its improvisational and flexible aspects. For the Chinese, the boundary between pilgrimage and tourism is sometimes difficult to draw clearly (Oakes and Sutton 2010). Many pilgrims, when asked why they participated, frequently answer: "We come for fun" (women lai wan), and in fact much of their time was spent visiting cities and scenic spots. For example, reaching Baishuiyang, a new tourist spot promoted by the Ningde government, involved traveling a long route that circled to the northeast of Fujian. Also, as the itinerary shows, three out of the five days were spent in the vicinity of Fuzhou, and once there the pilgrims immediately went their separate ways; those in politics and business did their share of networking, while those interested in buying houses went to see prospective properties. Still others went on shopping excursions, or for a massage. The actual worship at Changle Temple took up only one morning.

Given that the pilgrimage tried to juxtapose and satisfy so many disparate aims, it was inevitable that paradoxes and contradictions would arise. For instance, the organizers deliberately arranged to visit Gutian first, both to promote the Lady of Linshui in Matsu and to attract her followers in Taiwan to pass through Matsu when making pilgrimage to her root temple in Gutian. To do so, they opted not to journey directly to Changle, where the main deity of Ox Horn came from, but rather made the Lady of Linshui the focus of the pilgrimage. Although the Lady of Linshui is commonly worshipped in Matsu, she is considered a deity of lower status. In the new Ox Horn temple, she is ranked fifth among the eight deities. The route's itinerary therefore implied an inversion of the deities' hierarchy, and this sparked protests from elders who insisted the pilgrimage should first visit Changle, the ancestral temple, before proceeding to Linshui Temple or elsewhere. Although Cao Eryuan was able to persuade them that "what comes later is more important" (houzhe weida), this modern pilgrimage clearly gave greater prominence to political, economic, and entertainment aspects than to its traditional religious meanings.

This pilgrimage is only one of many new rituals which were designed to connect Matsu with China and Taiwan. Many other novel religious 
material practices - such as promoting the myth that "Goddess Mazu [was buried] in Matsu" and constructing the Goddess's sacred siteswere invented to attract people to visit Matsu.

\section{Sacred Constructions, Material Echoes}

The name "Matsu" was originally taken from the "Mazu" temple. This temple is also called the Tianhou Temple, and it has always occupied a special place on the islands. ${ }^{1}$ Indeed, all of the powerful figures of Matsu want to leave their marks on this temple. As I stated in Chapter 1, when the pirate Zhang Yizhou defeated Lin Yihe in 1942, he reconstructed Tianhou Temple and set up a stele to commemorate his victory. During the WZA period, the military took pains to manage and maintain the temple. The projects to rebuild the temple were all funded by the military: the cement reconstruction in 1963 and the renovations in 1983 were both completed by soldiers. Upon completion, the military commander came in person to host each inauguration. ${ }^{2}$ The temple management had to follow his instructions, and the annual ceremony to celebrate Mazu's birthday was arranged by him and hosted by the county commissioner. Military cadres of all ranks and officials from the central government in Taiwan also frequently visited and toured the temple. ${ }^{3}$

When the military rebuilt the Tianhou Temple using cement in 1963, the commander erected a stele:

Reconstruction of the Mazu (Tianhou) Temple

The Goddess Mazu was a girl surnamed Lin who lived in Meizhou in Fujian during the Song Dynasty. She showed remarkable filial piety. Her father and brother met with an accident when fishing at sea. She threw herself into the sea to save them but died afterwards. Her corpse floated to this island. Later, she performed many miracles to protect fishermen at sea. In gratitude for her grace, the people built a temple here and renamed this island as Matsu. During the reign of the Kangxi Emperor, Mazu was proclaimed to be "The Queen of Heaven." At a time when the Red menace was ascendant, and the people were dispirited, I was given an order to protect this island and pacify the bandits. As commander of an army, I understand that the mind is the most important. [I have to] protect the political boundaries, enrich people's lives, and correct society's trends as well as people's thoughts. I have the responsibility to protect this land, administer the territory, and reform 
society. We deeply understand that the heart is the root of everything, and filial piety is the most important of all virtues. The deeds of this pious girl can serve as an example of virtuosity. Her filial piety shines as brightly as the sun and moon. This temple has been rebuilt in honor of her virtue. This stele shall forever commemorate her virtues in stone.

Commander of the Matsu Garrison Area Lieutenant-General Peng Qichao Erected in Autumn of 1963

\section{重修媽祖廟（天后宮）碑記}

媽祖娘娘宋代閩省泥洲林氏女, 事親至孝, 父兄捕魚遇難, 投海䚇親, 殉身 抱屍漂流斯島, 後常顯靈異, 護佑漁航沿海。居民感受恩澤, 立廟宇尊祀, 易島名曰馬祖。康熙年間冊封天后。時際紅禍横流, 人心陷溺, 超奉命戍守 斯島, 進巢寇逆, 治軍之餘, 身體治心為本, 固疆囯裕民主, 端風氣正人心 守土有責, 庶政並舉, 正本清源。深維心為萬事主, 孝居百行先, 而孝女之 事蹟足式懿範可風, 孝義足昭日月, 廟時宜享千秋。敬重修廟宇以張孝烈, 用勒於石, 永崇祀典。

馬祖守備區指揮官 陸軍 中將彭啟超撰書 中華民國五十二年仲秋 吉立

The stele records that after Lin Moniang jumped into the sea to save her father and brother, her corpse floated to the edge of Mazu bay; her remains were buried where the Tianhou Temple is located now. From the inscription as a whole, one can be sure that the commander clearly understood that "the heart is at the root of everything" during cross-strait wartime, and "filial piety is the most important of all virtues." He erected the stele to praise Goddess Mazu for trying to save her father's and brother's lives and sacrificing herself; the implication, of course, was that the army and residents were similarly attempting to protect Taiwan. Although there is no actual evidence to confirm that the corpse of Goddess Mazu floated to the Matsu Islands, emphasizing her sacrifice could provide a boost to the morale of soldiers and residents in the battlefield and a means of acclaiming their own sacrifices for the country.

Locals have varying opinions about whether the goddess's corpse floated to Matsu. For example, the local gazetteer, The Annals of Lianjiang County (Lianjiang xianzhi), recorded this legend (Lianjiang xian 1980: 63); however, another gazetteer, Records of the Matsu Islands (Matsu liedao zhi) (J. Lin 1991: 236), questioned whether it was possible for the corpse of Lin Moniang to float all the way to the Matsu Islands, 
given that the distance between Putian and Matsu is over 100 nautical miles, which is approximately the distance between Matsu and Taiwan. I also asked many elderly Matsu residents their opinions about the myth. Most were unable to describe any details predating the arrival of the ROC army. They recount that Tianhou Temple was taken over by the navy command post which moved out after a fire. When I asked what the tomb was like at the time, a few elderly people who could vaguely remember said that it was "under an altar covered with a red tablecloth," so they could not see it. In short, none of them was able to recall what the tomb was like during the military reign, or indeed whether there even was a tomb. Some said that the military had once tried to build a cement floor to make the ground more level but that the cement above the tomb cracked the very next day. There are also rumors that when the temple was being reconstructed in 2000 , the earth auger used to drill the cement cracked when trying to drill the area around the tomb; as a result, the tomb was not moved. Whether these legends are true or not, they have successfully created an atmosphere of mystery surrounding the tomb. The stele and these tales have become an important basis for the temple to promote the myth of "Goddess Mazu in the Matsu Islands."

From another perspective, the development of the floating corpse myth is congruent with the geographical and cultural context of the islands. In the past, it was common to find corpses floating to Matsu, owing to its island geography. According to Chinese custom, the remains had to be carried to land and buried; after some time, a little shrine or temple may have been erected because of spiritual apparitions. This kind of phenomenon was not uncommon in Matsu or other islands $(\mathrm{H}$. Wang 2000; Szonyi 2008: 184). In fact, on the Matsu Islands, which encompass an area of less than 30 square kilometers, there are thirteen shrines or temples which can be traced to floating corpses (Lin and Chen 2008: 110). Thus, the myth of Goddess Mazu's corpse floating to Matsu and being buried there does not conflict with the geographical situation and cultural practice of the islands.

Tianhou Temple holds special significance for the Matsu people. It is located in the village of Matsu in Nangan, right on Matsu Bay and comprises several preexisting villages in the surrounding area, which were grouped together and established as an administrative village by 
the army. During the early war period, supply ships landed at Matsu Bay and transported people and goods back and forth between Matsu and Taiwan. People traveling to other islands, such as Beigan or Juguang, had to wait at Matsu Bay for the high tide before they could return to sea. Before the deepwater pier at Fu'ao was completed in 1984, Matsu Bay was the most important link between the archipelago and the outside world.

Tianhou Temple is located right in front of this very important bay. When residents left for or returned from Taiwan, the temple was right there to greet them. Gradually, the temple came to occupy a special place in the residents' life experiences. In fact, I often hear people say, "It is the place where we wait for the boat. The seas can be dangerous, so everyone burns incense at the temple to ensure safety." Today, in addition to their own village deities, many Nangan residents also go to the Tianhou Temple to worship Goddess Mazu during Chinese New Year. They say that their relatives living on other islands will even call to remind them to worship her. This collective experience of travel to Taiwan solidifies the importance of Tianhou Temple and Goddess Mazu in the hearts of most Matsu residents. This belief also served as the common basis for the later development of Goddess Mazu festivals.

Since 2000, a series of new religious and material practices surrounding the Goddess has appeared. When the Tianhou Temple was rebuilt in 2001, the temple committee added a burial vault in front of the sanctuary, emphasizing that it was the resting place of Goddess Mazu. As yin and yang must be separated, no temple in Taiwan would place a vault in front of a shrine, unless it is a ghost shrine (W. Lin 2018). But the Tianhou Temple daringly did it anyway to appeal to the adherents of Goddess Mazu. Immediately afterwards, the "Mazu in Matsu" slogan was proposed in 2004 (C. Chen 2011b), and then beginning in 2006, a "Mazu Ascension Ritual" was performed annually. In 2009, the temple built a giant statue of Goddess Mazu, modeled on a similar statue in Meizhou (Fig. 9.2). It reminds people that Meizhou is the birthplace of the Goddess, while Matsu is the place of her ascension, and encourages pilgrims to visit both places. It is through this "material echoing" that the residents of Matsu aspired towards a symbiosis with people across the strait so that both could prosper together. 


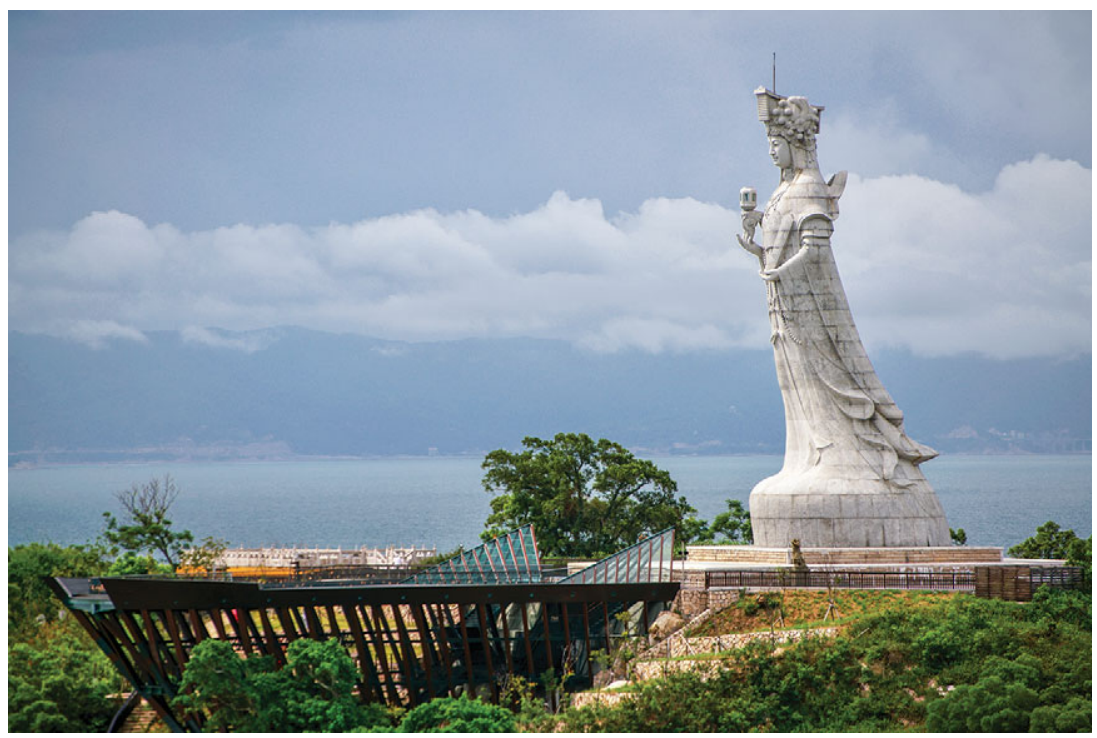

Fig. 9.2 The giant statue of Goddess Mazu on a boat (Photo by Yang Suisheng)

\section{Exploratory Journeys of Increasing Scale}

The Ox Horn pilgrimage can also be understood in the context of a series of pilgrimages that took place in the first decade of this century: that is, three other direct-sailing pilgrimages, and a pilgrimage-like exploration. Together, I show how the Matsu people deployed these rituals to confront the drastic changes in the cross-strait relationship during the period 2000-10.

Matsu people apply the term "direct-sailing" in a way that is slightly different from the general usage. "Direct-sailing" generally refers to traveling directly between two political entities that share no diplomatic relations, which usually requires going through a third country. However, Matsu residents apply the term to any significant travel by ship, even within the same country. Thus, a journey from Matsu to a city in Taiwan, both within the "Republic of China," is still referred to as a "direct-sailing" trip. This local interpretation shows again how much they value their role in directly connecting different places.

The first direct-sailing pilgrimage was from Matsu to Meizhou, China, via Mawei port. On New Year's Day 2001, the "three small links" were 
officially launched, allowing direct voyages from Jinmen to Xiamen, and from Matsu to Mawei. ${ }^{4}$ Owing to disagreements with the Chinese government, the small three links were only implemented unilaterally by Taiwan. Skirting sensitive political issues, the Matsu government organized this first pilgrimage in January to mark the beginning of the three small links. The pilgrims arrived in Mawei by boat and took a bus to Meizhou, the birthplace of Goddess Mazu. The political significance of this pilgrimage was that of breaking the ice of cross-strait tensions.

By 2007, Taiwan and China had already maintained different kinds of contacts for several years, and a substantial number of Taiwanese tourists had visited the mainland. That year, the second direct-sailing pilgrimage was launched to promote Matsu's religious tourism. This trip, again from Matsu to Meizhou, and advertised as a journey from Goddess Mazu's burial site to her birthplace, was intriguingly named the "Sacred Sea Route" (haishang shengdao), in emulation of the ancient Silk Road. It was hoped that it would become a model route that Taiwanese pilgrims take through Matsu and on to Meizhou (Matsu xiangqin 2007). The "Goddess Mazu in Matsu" idea and a series of religious practices drew the attention of people on both sides of the strait, particularly in the homophonous "Lianjiang county" in China. Since 2007, Matsu's Tianhou Temple has been invited to participate in the "Mazu Cultural Tourism Festival of Lianjiang" and vice versa. This religious exchange has gone well beyond the previous interactions in scale.

The third journey, called "Direct-sailing to Taichung," was organized in September 2008, with a ferry going directly to Taichung Harbor in Taiwan, and pilgrims then going on to visit the Mazu Temple in Dajia. The group continued north and visited areas where Matsu emigrants had settled and other places with temples connected to those in Matsu. The purpose of this pilgrimage was to foster exchanges between the temples in Matsu and those in Taiwan (Mazu jinshen 2008).

A more unusual kind of pilgrimage occurred in 2009, when the temple and the county government sponsored Li Xiaoshi, a retired lieutenant colonel from Matsu, to lead an expedition to climb Mount Everest. After retiring from the military, $\mathrm{Li}$ devoted his leisure time to mountain climbing and painting. Upset by the fact that most Taiwanese consider 


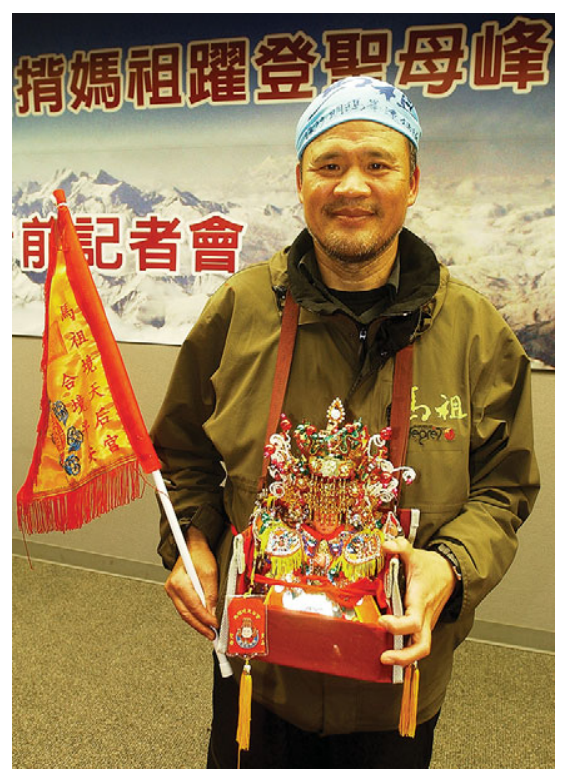

Fig 9.3 Li Xiaoshi carrying a figurine of Goddess Mazu (Photo by Chen Jianing)

his homeland to be just an offshore military outpost, he decided to undertake the most difficult challenge he could think of: climbing the world's highest peak, Mount Everest, with the goal of generating publicity and so introducing Matsu to outsiders. He realized that to safely climb Everest, he needed the protection of divine power. Thus, he gradually formed the idea of carrying a statue of Goddess Mazu to Mount Everest.

As he was casting about for funds for his expedition, the county government heard about his plan. Seeing an opportunity to promote tourism in Matsu, the government decided to give Li NT\$2,000,000 in sponsorship. Mazu Temple also contributed NT\$300,000 and made a $16 \mathrm{~cm}$ high figurine of Goddess Mazu for him to carry to the peak (Fig. 9.3). Since Mount Everest in Chinese is called "Mountain of the Sacred Mother" (Shengmu feng), and because this female connotation easily allows for an association with Goddess Mazu (whose official title is "Heavenly Sacred Mother"), this journey bore all the markings of a 


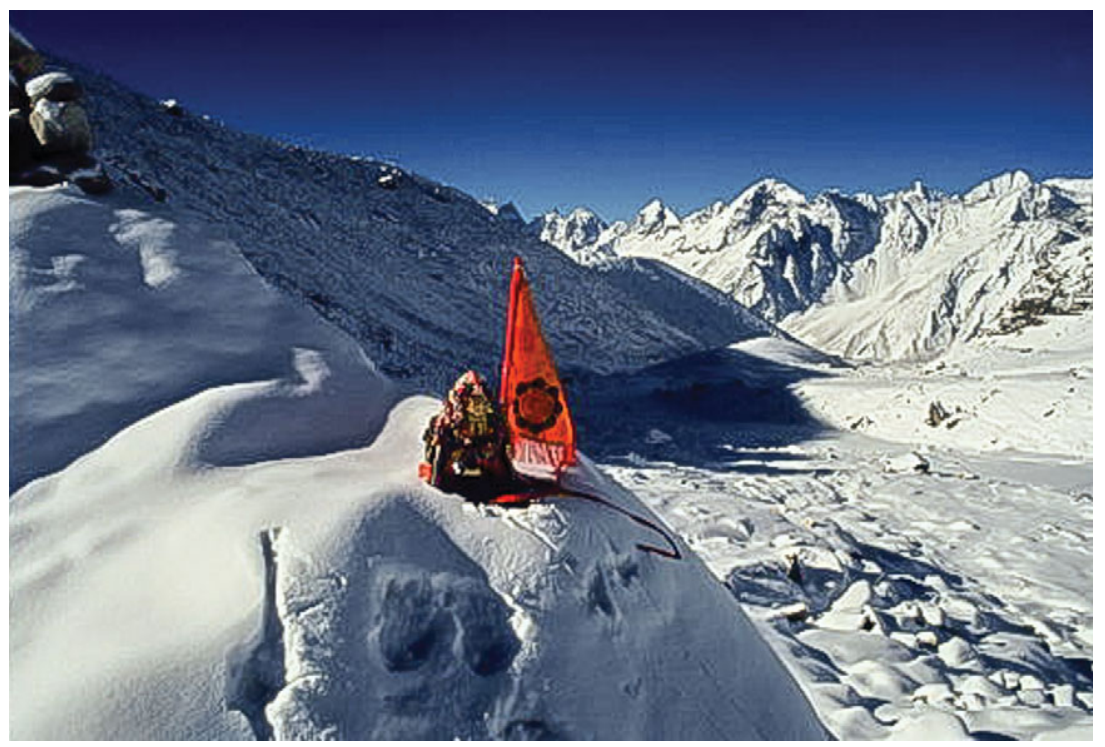

Fig. 9.4 Goddess Mazu heading for the peak of Mount Everest (Photo by Li Xiaoshi)

pilgrimage. Indeed, the explorer was ceremonially sent off and heroically welcomed back with rituals, firecrackers, and drums.

On his way up the mountain, Li regularly sent pictures back to Matsu showing how he and Goddess Mazu were progressing towards the highest peak in the world (Fig. 9.4). The Tourism Bureau immediately forwarded these photos on to The Matsu Daily and posted them on their website as they received them. The photos were given labels such as "Goddess Mazu on the peak of Mt. Everest," "Goddess Mazu also climbs to the summit of Mt. Everest" and "Carrying Mazu to the peak of Mt. Everest," emphasizing the significance of Li's epic adventure (C. Cao 2009a; 2009b). Thanks to Xiaoshi's strenuous expedition, the two "sacred mothers" finally met. It was a moment that Matsu locals had been awaiting with bated breath; a moment when they imagined that they would at last be connected with the wider world! Li's adventure was of great significance because he brought the hopes of Matsu to humanity at large. The residents of Matsu not only longed to be linked to Taiwan and the mainland, but also desired to be seen by the world. Goddess Mazu 


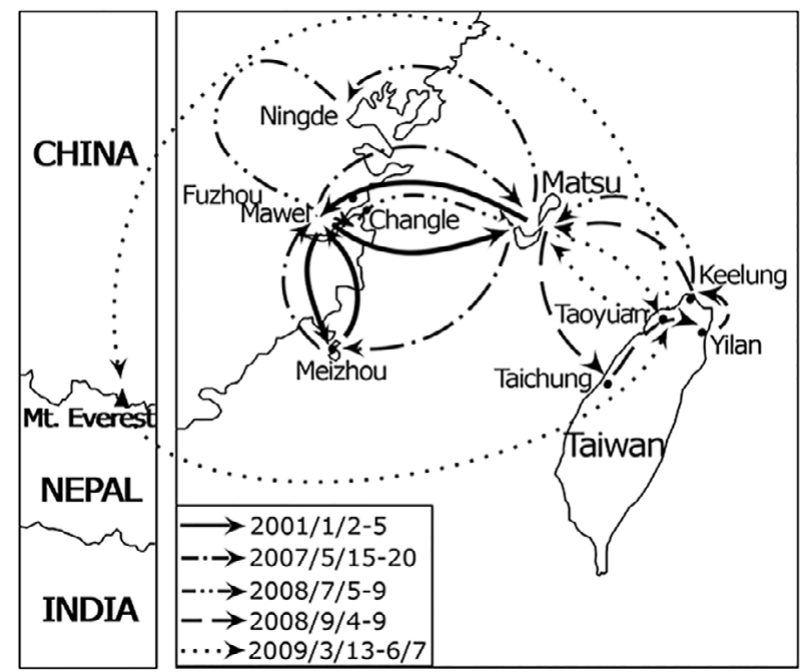

Map 9.2 Four direct-sailing pilgrimages and an exploratory journey to Mount Everest (not drawn to scale)

being carried up the mountain on the back of a Matsu local brought them one step closer to that goal.

\section{Recentralization Imagined}

Distinctive features of these Matsu pilgrimages can be seen more clearly from the routes pictured in Map 9.2, which, though somewhat complicated, shows how the Matsu-organized pilgrimages differ from Taiwanese pilgrimages in general. First, their timing betrays a lack of the regularity that is typical of Taiwan pilgrimages: they were improvised spontaneously to meet various needs. Second, the Matsu pilgrimages were deliberately designed to fulfill different purposes-depending on the particular needs of the local society, they could be organized to promote political communication, increase tourism, or expand networks. Finally, Map 9.2 most prominently shows that these routes were designed to create new connections, either with China, Taiwan, or the world. They represent the islanders' dreams of recentralization.

Note, too, that all of these pilgrimages occurred during a period when cross-strait relations were rapidly changing: tensions between Taiwan and China were improving, but a consensus had not yet been 
reached as to how their relations should develop. Those on Matsu, sensing the imminent danger of being forgotten in the new circumstances, were relentless in their attempts to attract the attention of both sides through pilgrimages. That is why these rituals appear to be contingent, instantaneous, and improvised, and inflected with fictive and novel tones (see Harvey 1990). To wit, they were performanceoriented, and intended to create more dramatic effects. Unlike traditional pilgrimages, they were eclectic in their combinations of different elements. Each was thus a peculiar religious reconfiguration in response to changing political and economic contexts. Together, they show the Matsu people's strong desire to engage with, and even to break, the constraints that came with being caught between the shifting tides of cross-strait relations.

\section{A Mere Illusion?}

Observing how the Matsu Islanders continue to change pilgrimage routes so as to forge more connections, several questions might be posed: Have Matsu residents succeeded in creating these economic, political, and religious links? What concrete results have the pilgrimages brought about? How much trade has flowed between Keelung, Matsu, and Ningde, and how many tourists? These questions do not seem to be important ones for the pilgrims or the temple committees themsleves. The organizer of the Taiwan-Matsu-Ningde direct-sailing pilgrimage, Cao Eryuan, described their significance like this:

In the future each island will be able to radiate out its own connections to the mainland, creating its own chances of survival.

In other words, Matsu residents recreate pilgrimages to generate possibilities for future development. Contemporary Matsu pilgrimages are thus like blueprints for the future, or to use Miyazaki's phrase, they are "methods of hope" (2004). They point to a future world that the Matsu people aspire to participate in.

The success of the pilgrimage to Ningde aroused the interest of Wenzhou in Zhejiang Province, the northernmost city in the CrossStrait Economic Zone. City officials proactively contacted the Ox Horn temple committee and invited the people of Matsu for a visit. After 
visiting the Zhejiang administration in 2008, the committee soon planned a second trip that went through Fuzhou, moved north to Wenzhou, and finally arrived at Ningbo (July 6-11, 2010). This journey was not called a pilgrimage, but instead was referred to as an "incense exchange" (huixiang) between temples. However, in contrast with the traditional exchanges between temples in Taiwan, the people from Matsu conveyed no deity statues or incense burners, nor did they play gongs or drums. ${ }^{5}$ The team's leaders carried only incense flags and used them just to indicate directions their team should move in, much as tour guides do. Though the group visited a Buddhist sacred site, Mt. Putuo, it did not meet the heads of the temple there. Generally speaking, the religious significance of this exchange was peculiarly downplayed. Its main purpose was revealed by the group's official title-the Pioneer Group to Zhejiang from Matsu, Taiwan - which was meant to emphasize that this group from Matsu was the largest entourage from Taiwan to have visited Zhejiang. The temple committee had the participants wear uniforms to show their unity, and indeed 450 people appearing in bright orange uniforms was a magnificent sight.

However, the connections that the Matsu people longed to forge through their pilgrimages and religious exchanges suffered setbacks during this 2010 trip, owing to changed external circumstances. The Wen-Fu High Speed Rail, commissioned in 2009, greatly shortened the journey between Wenzhou and Fuzhou, allowing people from Taiwan to fly directly to Fuzhou (following the official opening of the "three great links") and conveniently proceed to Wenzhou. Officials from the latter city therefore no longer had a strong incentive to encourage visits through the sea route from Matsu. Without reaching any consensus with these officials regarding the trip's itinerary, the $\mathrm{Ox}$ Horn temple committee decided to travel by railway and had only a short layover at Wenzhou. Though the original purpose of the trip had been to facilitate connections between Matsu and Wenzhou, the leaders of the two sides did not interact at all.

Equally telling was the way they were received in Ningbo City, the trip's final destination, to which direct flights from Taiwan are now available. A local newspaper referred to them as a "tourist group" (Peng 2011) and only travel agents were sent to accompany the people 
from Matsu as they toured Ningbo. The highest-ranking official they met was the relatively junior deputy director of market development, a department of the city's Tourism Bureau. This was in stark contrast to what the Matsu people had experienced in Ningde two years before. On the Ningbo trip I frequently heard them reminiscing about the highprofile reception they had enjoyed in Ningde and wondering why they were not being escorted by police cars. One woman told me, "I miss the gongs, drums, firecrackers, and boisterous atmosphere (re'nao) of the Ningde trip."

Indeed, the Zhejiang exchange could not compare on any level with the journey to Ningde-in neither Wenzhou nor Ningbo was it considered an important political, economic, or even religious event. Undoubtedly, the status of Matsu in the cross-strait relationship had quickly diminished due to macro politico-economic developments, including new direct flights and sea travel between China and Taiwan, China's regional policies, and its greatly improved transportation infrastructure. In the midst of these fast-changing neoliberal dynamics, this trip nearly dashed the islanders' dream of recentralizing Matsu between China and Taiwan by means of pilgrimages and religious exchanges.

It is undeniable that, lacking political, economic, or religious significance, the pilgrimage was little more than a sightseeing tour. For the temple committee, however, the trip still had importance: "We have already gone beyond Fujian, and moved northward to Zhejiang." In other words, the imagination entailed in pilgrimages and religious exchanges continues to generate opportunities and hopes. On the way home, I heard discussions about their next destination: Tianjin in northern China.

\section{Conclusion: Explorations of Potentialities}

While on the 2008 pilgrimage to China, I was surprised to learn that, like me, the Matsu people were unfamiliar with Ningde. But I was reminded of something once said by a ninety-year-old Matsu immigrant living in Taiwan, who had once been a fisherman: "Before Chiang Kai-shek's troops came over, people from Ningde or even further north would come by boat to Matsu to buy fish. At that time, Matsu people could travel 
anywhere. Matsu was a free place then!" The war separated the two sides of the Taiwan Strait and isolated the Matsu Islands. Today, the people of Matsu are trying to use religion to reestablish links between the two sides. The new temple in Ox Horn has created a new sense of identity for the residents, and the process of building a temple and traveling across the Taiwan Strait has strengthened relations on both sides. After the completion of their new temple, the Ox Horn residents took their deities on a pilgrimage to the ancestral temple in mainland China, witnessing and commemorating the bitter history of separation over the previous fifty years (see Jing 1996).

However, there is more to the Matsu pilgrimages than cross-strait reunion or religious renewal. In earlier times, Matsu merely served as a temporary stopover for fishermen, and most of the cultural activities were performed on the mainland. Since pilgrimages and other important rituals were never a part of Matsu's historical tradition, the islanders can be relatively spontaneous and improvisational in planning them now. In other words, although the Matsu pilgrimages may be inspired by those in Taiwan (M. Yang 2004; Hatfield 2010; Stewart and Strathern 2009), they are in fact quite different.

In this chapter, I have shown that these novel religious practices are imaginative works designed to attract attention from both sides of the Strait. I collectively refer to these imaginative qualities as "virtual recentralization." "Recentralization" connotes the Matsu islanders' longing to regain their important Cold War status as the focal point between China and Taiwan, even though this longing is "virtual" rather than real, as cross-strait tensions continue to be mitigated. These practices won the support of most of the Matsu locals, because they generate hope, potential, and point to future possibilities at the turn of the twentyfirst century, when the Matsu Islands faced a strong sense of uncertainly.

Following along these lines, I posit that each of these rituals, myths, and material practices was not only a response to, but also a specific reconfiguration of, the dizzying political and economic changes in the relationship between China and Taiwan during this period. This is why the forms of all these religious practices appear to be improvised, contingent, and suffused with elements of fiction and fantasy. They differ from traditional religion in important ways: they are oriented toward 
performance and novelty, rather than transmitting permanent and solid religious values. Each attempt seeks a new kind of connection between the two lands, one that is more eclectic in purpose and less sovereign.

As these newly invented religious practices are the imaginary reconstitutions of cross-strait realities, they are inevitably susceptible to oscillations in the macro China-Taiwan relationship, as a result of which recentralization is sometimes on the verge of vanishing. However, I consider that the significance of these new rituals, myths, and material practices rests not on whether they succeed, but on the subjectivity they convey when people are faced with predicaments; they mediate social relations, rescale regional interactions, and forge possible developments for the islands in the future. 